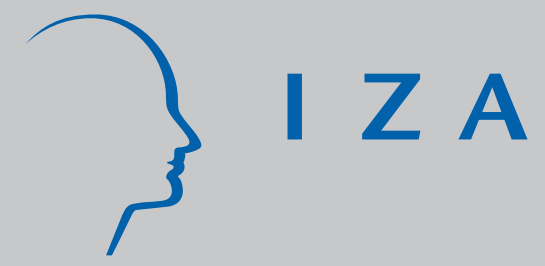

IZA DP No. 6526

Temporary Employment, Job Flows and Productivity: A Tale of Two Reforms

Lorenzo Cappellari

Carlo Dell' Aringa

Marco Leonardi

April 2012

Forschungsinstitut zur Zukunft der Arbeit Institute for the Study of Labor 


\title{
Temporary Employment, Job Flows and Productivity: A Tale of Two Reforms
}

\author{
Lorenzo Cappellari \\ Catholic University of Milan \\ and IZA \\ Carlo Dell'Aringa \\ Catholic University of Milan \\ Marco Leonardi \\ University of Milan \\ and IZA
}

\section{Discussion Paper No. 6526 \\ April 2012}

IZA

P.O. Box 7240

53072 Bonn

Germany

\author{
Phone: +49-228-3894-0 \\ Fax: +49-228-3894-180 \\ E-mail: iza@iza.org
}

\begin{abstract}
Any opinions expressed here are those of the author(s) and not those of IZA. Research published in this series may include views on policy, but the institute itself takes no institutional policy positions.

The Institute for the Study of Labor (IZA) in Bonn is a local and virtual international research center and a place of communication between science, politics and business. IZA is an independent nonprofit organization supported by Deutsche Post Foundation. The center is associated with the University of Bonn and offers a stimulating research environment through its international network, workshops and conferences, data service, project support, research visits and doctoral program. IZA engages in (i) original and internationally competitive research in all fields of labor economics, (ii) development of policy concepts, and (iii) dissemination of research results and concepts to the interested public.
\end{abstract}

IZA Discussion Papers often represent preliminary work and are circulated to encourage discussion. Citation of such a paper should account for its provisional character. A revised version may be available directly from the author. 
IZA Discussion Paper No. 6526

April 2012

\section{ABSTRACT \\ Temporary Employment, Job Flows and Productivity: A Tale of Two Reforms ${ }^{*}$}

We investigate the effects of two reforms of temporary employment using panel data on Italian firms. We exploit variation in their implementation across regions and sectors for identification. Our results show that the reform of apprenticeship contracts increased job turnover and induced the substitution of external staff with firms' apprentices, with an overall productivity-enhancing effect. The reform of fixed-term contracts instead did not produce the intended results: it induced a substitution of temporary employees in favour of external staff and reduced capital intensity, generating productivity losses. We estimate substitution elasticities across various types of temporary contracts that are consistent with this interpretation.

JEL Classification: J24, J41

Keywords: employment contracts, productivity, institutional changes

Corresponding author:

Marco Leonardi

Department of Economics

University of Milan

Via Conservatorio 7

20122 Milan

Italy

E-mail: marco.leonardi@unimi.it

\footnotetext{
* We thank Tito Boeri, Juan Dolado, Michael Kvasnicka and three anonymous referees for providing extended comments on the paper, and seminar participants at Catholic University of Milan, AIEL, EALE-SOLE, ESPE, the FEDEA/FRDB/IZA Conference on "Dual Labor Markets and the Single Contract" and the IAB Workshop on "Labour Market Flexiblility-Boone or Bane?" for useful remarks. We are also grateful to Domenico Mauriello of Unioncamere for his help with the Excelsior-Asia data. A previous version of this paper has been circulated as CESifo Working Paper 3520. The usual disclaimers apply.
} 
In the past two decades the major policy response to high unemployment rates in Europe has been the reduction of Employment Protection Legislation (henceforth EPL) through the liberalisation of temporary contracts. ${ }^{1}$ A large literature has established the importance of temporary contracts in affecting job flows by increasing both the hiring and the firing of workers. Although much less researched in theory and in practice, it is plausible that temporary contracts also have a bearing on firms' capital investment decisions, on the capital-labour ratio and, eventually, on productivity. While the effects of EPL on productivity have been assessed in the past (see Autor et al., 2007; Bassanini et al., 2009; Cingano et al., 2010), the productivity impact of reforming the regulation of temporary contracts has never been evaluated using firm-level data. In the debate on whether liberalisation of temporary contracts is good or bad for the economy, productivity effects play a crucial role and our key contribution is to provide this type of evidence at the micro level.

The purpose of this paper is to evaluate the effects of the institutional changes of two different types of temporary contracts which constitute the core of recent labour market policy in Italy. We analyze the effects of these changes on job flows, employment, capital-labour substitution and productivity. The first institutional change has to do with the implementation of a national law (legislated in 2001) which eased the use of fixed-term contracts by relieving employers from the obligation of writing the specific reason for using temporary workers in the employment contract. While the law set out nationally a general framework for the use of fixed-term contracts, the actual implementation of its provisions required their approval through the rounds of collective bargaining that took place sectorwise in the subsequent years (starting in 2005, much later than the national law).

\footnotetext{
${ }^{1}$ Among the countries in the European Union, France, Italy, Germany, Spain and Portugal liberalised temporary contracts over the 1980s and 1990s. For a general discussion see Boeri (2011).
} 
Therefore the timing of the implementation across sectors varied according to the staggered structure of collective bargaining rounds. This feature generates variation across sector and over time in firms' exposure to the new provisions which we exploit in estimation. The second reform concerns apprenticeship contracts for young workers. It was meant to stimulate the use of these contractual arrangements mainly by weakening the need of training certifications and extending the scope of their applicability to individuals up to 30 years of age. The relevant law was legislated in 2003 but required regional governments to issue implementation guidelines, which happened differentially by region in the subsequent years (also starting in 2005). This feature of the legislative process generates variation across regions and time in firms' ability to use the new contracts.

A further contribution of this paper is that we estimate the elasticity of substitution between different types of temporary contracts. Economic models necessarily simplify the actual use of temporary and permanent contracts and consider one single type of temporary contract. However in practice in all countries there exist different types of temporary contracts, typically the result of repeated attempts at making the labour market more flexible leaving the open-ended contracts untouched. Italian employers can use four types of temporary contracts with different characteristics: apprenticeships (Apprendistato), fixed-term (Tempo Determinato), collaboration workers (Collaborazioni Coordinate e Continuative, the so called co.co.co, a sort of consultant employed on a temporary basis) and temporary agency jobs (Interinali). These contracts differ along various dimensions such as illness provisions, minimum wages, age restrictions, temporal limits and number of allowed repetitions of the same contract. The perception among labour lawyers and entrepreneurs is that they are highly substitutable but so far there is no hard evidence of this. We have firm-level data on the use of the four different types of temporary labour contracts and on permanent ones and we show that the effect of 
the reform of one type of labour contract may work also through the substitution with other types. This is the first paper, as far as we know, which studies the substitutability across different types of temporary contracts and highlights the potential consequences of a high elasticity of substitution. The substitution across different types of temporary contracts represents an important mechanism at the basis of our results.

We find that the reform of apprenticeship contracts has been successful because it increased the turnover of workers easing the adjustment process of firms, encouraged the substitution of external staff with apprentices and eventually increased productivity. The reform of fixed-term contracts, instead, does not seem to have had the intended results. By removing the requirement of a specific reason for using a fixed-term contract, the new regulation may have been too generic and in case of disputes too dependent on judges' interpretation of the norm. This increased employers' uncertainty and may have made the use of fixed-term contracts less costly but more risky. This reform reduced overall job turnover, induced substitution with external staff and a lower use of capital per worker, which eventually reduced various measures of firm-level productivity.

The paper proceeds as follows: in Section 1 we review the literature, in Section 2 we describe the institutional changes, in Section 3 we describe the data, in Sections 4 and 5 we present, respectively, the estimation framework and the results and we conclude in Section 6.

\section{Related Literature}

Temporary contracts are typically used for different reasons: for screening purposes, to temporarily fill in for staff who are absent or leave, or to accommodate fluctuations in demand. In many cases employers also save in labour costs and 
social security benefits using temporary contracts (Houseman, 2001). Temporary jobs inhibit labour market advancement if these jobs displace more productive employment activities. However they may also increase employment and earnings if they substitute for spells of unemployment. The effect of temporary contracts on productivity depends on whether temporary positions on average complement or displace permanent jobs. In this respect the literature on temporary jobs which mostly looks at the employment effects rather than wage effects - is very heterogenous and does not draw a general conclusion.

Using a natural experiment Autor and Houseman (2010) show that temporary help positions reduce earnings and employment probabilities in the United States. Kvasnicka (2009) finds that holding a temporary contract after a spell of unemployment has at best a null effect on the probability of finding a permanent job. With an eye to European labour markets, Blanchard and Landier (2002) and Cahuc and Postel-Vinay (2002) model temporary contracts as churning policies that affect negatively wage setting and may generate higher unemployment and lower productivity. Contrary to this pessimistic vision, if fixed-term contracts are used as a buffer-stock to boost the number of hirings in a boom, employment and productivity may go up at least temporarily (Boeri and Garibaldi, 2007). Some papers show that being assigned to a temporary contract has a causal effect on the probability of finding a permanent match (for example Ichino et al., 2008; Booth et al., 2002). According to this view temporary contracts are good screening devices and stepping stones into permanent jobs and therefore increase productivity. While existing studies on temporary employment have been considering all these aspects, an empirical evaluation of the relationship between liberalisation of temporary contracts and firms productivity is still missing in the literature so far.

The specific literature on temporary contracts is also strictly related to the more general one on EPL. In continental Europe many countries relaxed the rules 
about the use of temporary contracts with the aim of reducing adjustment costs for firms facing high EPL for standard open-ended contracts. Therefore the reforms designed to make the use of temporary contracts easier constitute a reduction in EPL but also create dual or two-tier labour markets (see Dolado et al., 2002, for Spain; Holmlund and Storrie, 2002, for Sweden). ${ }^{2}$ EPL raises the cost of employing workers and reduces labour demand unless wages fall to cover exactly the cost of the benefit (Lazear, 1990). ${ }^{3}$ Because part of EPL constitutes a tax that goes to third parties - lawyers and administrative costs - EPL is by all means an adjustment cost and there is overwhelming evidence that it reduces the volatility of employment (Bentolila and Bertola, 1990). In the following we do not review the huge literature on EPL and job flows and we concentrate on the literature that looks at the relationship between EPL and investment and between EPL and productivity. The effects on productivity and investment are theoretically ambiguous (Ljungqvist, 2002) but we use the insights of this literature to interpret our results.

On the one hand there are multiple mechanisms that may induce a negative effect of an increase in EPL on productivity. High EPL hampers the reallocation of workers and jobs across industries and firms by inducing substitution of specific for general skills (Wasmer, 2006); reduces workers effort (Ichino and Riphahn, 2005; Riphahn and Engellandt, 2005; Dolado et al., 2012); reduces the undertaking of highly productive but risky activities (Bartelsman and Hinloopen, 2005); and induces substitution between permanent and temporary contracts, reducing pro-

\footnotetext{
${ }^{2}$ The OECD produces different indices of employment protection, including one related to the regulation of temporary contracts only. When the index is built considering only the legal treatment of fixed-term contracts, the negative correlation between EPL and job flows is significantly stronger (Martin and Scarpetta, 2011). Autor (2003) shows that higher EPL induces a higher use of temporary agency jobs in the United States.

${ }^{3}$ Analyzing the 1990 Italian reform of EPL, Leonardi and Pica (2010) show that the fall in wages does not fully offset the increase of severance costs and conclude therefore that EPL imposes efficiency costs in the competitive model.
} 
ductivity (Cahuc et al. 2012). On the other hand various mechanisms indicate a positive relationship between EPL and productivity. More stringent EPL provides insurance and may promote specific investments (Belot et al., 2007); selects the most productive firms which withstand the costs of EPL (Poschke, 2009); makes firms become more selective with workers so that less productive matches are not realized (Lagos, 2006).

There are theoretical reasons to expect also an ambiguous effect of temporary contracts and EPL on the capital-labour ratio. In labour markets with no frictions an increase in the cost of labour will in general imply substitution of labour with more capital and therefore a positive relationship between EPL and capital-labour ratios. A related case arises in the long run: higher EPL means that labour is more costly and when adopting new technologies firms will choose more capital-intensive technologies (see among others Koeniger and Leonardi, 2007). Models with wage bargaining between workers and firms instead point to a negative relationship between EPL and capital-labour ratios. The protection of EPL strengthens the outside option of workers so that they may claim higher wages (Garibaldi and Violante, 2005). As a result, firms may reduce their investment ex-ante to avoid workers capturing part of the investment returns (the so called 'hold up' problem).

The empirical part of most of the existing papers on EPL and productivity is based on cross-country and/or cross-industry regressions which usually find negative relationship between EPL and productivity (Micco and Pagés, 2008; Cingano et al., 2010). However the approach based on country or industry data potentially suffers from the well-known severe problems of reverse causality and omitted variables. Furthermore most studies do not distinguish between EPL provisions for fixed-term and permanent contracts. In using firm-level data, our work is close to Autor et al. (2007) who study the impact of adoption of wrongful-discharge protection norms in the United States using cross-state differences in the timing 
of adoption. Differently from them we use a change in EPL that concerns the relaxation of rules about the use of temporary contracts which is typical of many European countries.

\section{Institutional Background}

Italian employers may choose to utilize labour inputs under a variety of employment contracts. The most typical form of contract is the permanent one, which has no termination and, depending upon firms characteristics (mainly their size), is characterized by relatively stringent EPL and, consequently, higher firing costs.

A second type of contract is represented by fixed-term contracts. The only difference between these and permanent ones is the presence of a fixed term and lower firing costs. A fixed-term contract can be renewed only once and its cumulated duration cannot be longer than three years in the same firm. Furthermore, employers have to state explicitly in the labour contract what are the reasons for using fixed-term in place of open-ended contacts. If either of the two conditions (limited duration and explicit reasons) are not met, an employee can sue the employer and eventually obtain from the labour court the conversion of the temporary contract into an open-ended one. The burden of the proof is on the employer, i.e. it is up to the employer to demonstrate the temporary nature of the fixed-term contract. All other working conditions such as wages, working times, pension rights and probationary period, are identical to the ones of permanent contracts.

Apprenticeships represent another form of temporary employment contracts. Differently from fixed-term ones, firms can use these contracts only for younger workers, for whom they must provide certified training. The legislation provides for lower social security contributions for apprenticeship contracts. The amount of this reduction, as the maximum duration of these contracts depends on the 
type and size of the employing firm: on average the firm pays social contributions which are one third of those paid for standard contracts. The maximum cumulated duration is three years.

There exists other contractual arrangements through which firms can use the labour services of external workers. As in many other countries there are temporary help agencies which supply labour services upon the payment of an agency fee. Agency workers must receive the same pay and the same working conditions as equivalent workers within the same firm. Because of agency fees the cost of using temporary agency workers is higher relative to hiring workers on permanent contracts. In exchange the user firm has lower hiring and firing costs to bear.

Additionally, and this is mostly an Italian peculiarity, firms can use collaboration contracts. These contractual arrangements are in place since the early 1970s and were regulated again with nationwide legislation in 1997 and in the 'Biagi Law' of 2003 (see below). They provide a contractual framework for individuals who are not formally employees of the firm and yet provide their regular working services (material or immaterial - i.e. consultants) to firms which often utilize them as normal employees. Thanks to a reduced regime of compulsory pension and other social contributions, which makes labour costs lower compared to regular employees, many firms use them to a very large extent.

In Table 1 we provide a synthetic view of the difference in employment across different types of contracts and their labour costs for firms in terms of social security contributions. Permanent contracts account for the vast majority of Italian employment, almost 15 million employees, corresponding to $84 \%$ of total employment. Among temporary contracts, fixed-term contracts are the most popular, followed by collaborators, apprentices and agency workers. Firms pay for permanent, fixed-term and agency contracts a social security contribution rate at $31 \%$ of gross earnings. Contributions rates are lower for collaborators and apprentices, 
at $17 \%$ and $10 \%$ respectively.

Similarly to other European countries, labour market flexibility has increased in Italy over the last decades as a result of a series of reforms which introduced various types of temporary contracts without changing the legislation on permanent, openended, contracts. The most important legislation was:

1. Law no. 196/1997 (the so called 'Treu-Package', named after the then minister of labour) which legalized temporary work agencies, regulated collaboration contracts and liberalized both apprenticeship and fixed-term contracts;

2. Decree Law no. 368/2001 which eased restrictions on fixed-term contracts further;

3. Law no. 30/2003 (the so called 'Biagi Law', named after the legal expert killed by terrorists) which introduced a number of changes in the national legislation and reformed the apprenticeship contract.

Our analysis considers data for the period 2004-2007 and focuses on the second and third of these reforms. These two measures were implemented at different times in different regions and in different sectors of the economy, generating variation in the institutional setting that allows us to use a difference-in-differences approach. Both measures, although legislated at the national level in 2001 and 2003, were implemented starting only in 2005 and therefore can be evaluated using the available data from 2004 to 2007 . We discuss each of the two measures in turn.

\subsection{The 'New' Fixed-Term Contract}

Legislative Decree no. 368/2001 introduced important changes to fixed-term employment contracts. They included two changes of particular importance for the purposes of this study. The first and definitely most important modification concerned what are termed the 'reasons', i.e. the circumstances in which this type of contract may be used. Prior to 2001 the law regulating fixed-term contracts 
provided a very specific list of circumstances under which firms could use those contracts, for example peaks in production or replacement of workers on sick leave. The new decree liberalized the contract by abolishing the detailed list of specific reasons and introducing the following single general reason: 'reasons of a technical, organisational, production or replacement nature'. In principle, this new legislation was meant to be less stringent than the previous one and to allow firms to use more fixed-term contracts to adapt quickly to changes in economic conditions (Tiraboschi, 2004). In practice, however, it might have had the opposite effects, making the requirements for the use of these contracts too generic and, in case of court disputes, too dependent on judges' interpretation of the norm (Aimo, 2006). In a country like Italy, where EPL is based on statutory laws and where labour courts have in general a restrictive reading of the norms, a higher scope for judges' interpretation of the law could be perceived by employers as a likely increase in the number of disputes. This uncertainty on whether or not hiring on fixed-term contracts would eventually result in a court appeal and -potentially - in the conversion into a permanent contract, might have actually reduced the incentive to use fixed-term contracts because complex and time-consuming legal processes can add significantly to the cost of hiring and dismissing workers (Venn, 2009). ${ }^{4}$ While there was a lively debate amongst labour scholars on whether this reform made the use of this type of contract more rather than less costly to firms, there is no empirical evidence on the effects of the reform on firms' choices. In this paper we attempt to fill this gap.

The second change introduced by the decree is the reduction of unions' ability to affect the implementation of national law provisions through collective bar-

\footnotetext{
${ }^{4}$ The relationship between labor cost uncertainty and court ruling has been also pointed out in Autor et al. (2007) who show that a substantial component of the economic cost of the employment-at-will exceptions emanates from the uncertainty they introduced into the employment relationship.
} 
gaining that takes place at the industry level. Under the previous legislation, collective bargaining agreements could list additional and specific reasons for the use of fixed-term contracts over and above those contained in the national legislation. The decree abolished all specific reasons, of any kind, including those contained in collective agreements, thereby reducing union power to bargain with employers' associations over the addition of further valid cases to the national list. The legislation maintained a role for collective bargaining in fixing the maximum percentage of fixed-term employees in firms' total employment. For this reason, the new law had to wait for the renewal of the collective agreement of that industry in order to become applicable in a given industry. In practice, all collective agreements confirmed the maximum shares of fixed-term contracts set in the previous bargaining rounds, so that the implementation of the reform did not introduce additional differences in employment flexibility across industries. All other aspects of the implementation of the reform were homogenous across industries.

We evaluate the effects of this reform using a difference-in-differences research design. The case of the new fixed-term contracts lends itself to this type of analysis since in order to become applicable in a given industry, the new decree needed to be implemented through the collective contracts for that industry. Therefore, only industries with contracts negotiated after the decree was legislated, could apply the new fixed-term contracts. In Italy, collective bargaining is staggered by industry and, after 2001, the renegotiation of collective bargaining agreements that implemented the new contracts at the sectorial level only occurred in some industries (Textiles, Wood Products, Chemicals, Construction, Transportation, Retail Trade, Food Products and Telecommunication), with contracts signed mostly in 2005 and 2006. Other important sectors of the economy such as Metal Manufacturing and Banking renewed the collective agreements during the period but decided to postpone the implementation of the 'new' fixed-term contract to a successive 
agreement that took place after the period covered by our analysis. ${ }^{5}$ We exploit such variation across industries over time.

\subsection{The 'New' Apprenticeship Contract}

Legislation to regulate apprenticeship contracts has existed for a long time and has also been reformed several times. The lower labour costs associated with these contracts make them particularly convenient to employers and are intended to compensate firms for the training costs that they incur. Firms are required to share training costs by giving apprentices time off work to attend external training courses that are provided by local authorities or accredited training institutes sponsored by the regions outside the premises of the firm. At the end of the training period, apprentices should receive a certificate for the qualification they have attained. There are, nevertheless, limitations to this formal training activity: lack of public funding for training, a lack of infrastructures for training courses and little control over compliance with compulsory training obligations by firms using these contracts. As a consequence most of the training is on-the-job.

The 'Biagi Law' liberalized this contract further. A new form of apprenticeship was introduced (apprendistato professionalizzante, literally apprenticeship leading to an occupation) with the same reduced labour costs as before. The new legislation abolished the certification of qualifications and extended the scope of the contract to include persons up to the age of 30 (the previous age limit was 25). The option of performing training at the workplace as a substitute, at least in part, for external training courses was also introduced. This last amendment made it even more difficult to monitor compliance with this obligation by firms. Before the new law could be implemented, regional governments, which have exclusive power to legislate over vocational training including the training content of the

\footnotetext{
${ }^{5}$ In Section 5 we assess the robustness of our findings to the inclusion of these two sectors.
} 
new apprenticeship contracts, had to issue regional regulations. The regions were in general very slow in issuing these regulations, partly because they lacked the funds needed to organize the external training for apprentices.

Although slow to act, some regions passed legislation earlier than others. No regions passed any guidelines in 2003 and 2004. Some regions enacted experimental projects for the new contract in specific sectors (mainly Retail Trade, Banking and Hotel and Restaurants). These experimental projects were implemented in $2005 .{ }^{6}$ In 2005 Emilia Romagna and Tuscany, enacted regional regulations to enable the use of the new contract by all firms. Another four regions followed suit in 2006: Friuli, Marche, Sardinia and the autonomous province of Bolzano. Finally, regulations were issued in Lazio in 2007. We exploit this variation over regions and time in a difference-in-differences framework. Additional institutional variation in the implementation of the new contracts was generated by Law no. 80/2005 which provided that in the absence of regional regulations, sector-specific collective agreements could specify the training content of the new contracts. Consequently, firms in those sectors whose collective bargaining rounds took place after the law was issued, could use the new apprenticeship contract. Collective agreements took place in: Textiles, Wood Products, Chemicals, Construction, Transportation, Retail Trade, Food Products and Telecommunication, Energy, Banking, and Metal Manufacturing. To sum up, institutional variation in firms' exposure to the new apprenticeship contract comes from three sources: regional, sectorial, and regionalsectorial (the latter deriving from the experimental projects of 2005).

\footnotetext{
${ }^{6}$ Details on the regional and sectorial implementation of the new apprenticeship contracts are provided by ISFOL (2007). In Section 5 we assess the robusteness of our results to the inclusion of these regional experiments.
} 


\section{$3 \quad$ Data and Descriptive Statistics}

The data set used in this paper is a balanced panel of about 13,000 firms in the private sector observed over the years 2004-2007, representative of the universe of corporate firms in the private sector. Firm-level information on the types of employment contracts used within the firm is derived from Excelsior, a survey conducted by Unioncamere (the Association of Italian Chambers of Commerce) with the aim of providing information on firms' occupational needs, in particular the skill requirement of prospective hires. It contains unique and detailed information on all the various contractual arrangements that Italian firms may adopt for utilizing labour services: permanent employment contracts, fixed-term employment contracts, apprenticeships, agency workers and collaborators. The data also provide details on the industry (3-digit) and geographical location of the firm, which is essential in constructing the treatment indicators of the reforms discussed in the institutional section. The other relevant piece of information used in the paper is the balance sheet information which is derived from the ASIA database, the archive of firm data maintained by the National Statistical Institute. ASIA data are available since 2004 and provide information on firms' value added, revenues and net physical capital stock.

Based on this information we can construct two treatment dummies capturing the exposure of firms to the two reforms discussed in the previous section. We identify exposure to the reform of fixed-term contracts using firms' sectorial affiliation. Treated sectors are the ones whose national collective agreements were signed after the nation-wide legislation was passed in 2001, and whose national agreements explicitly implemented the new legislation. These sectors were Textiles, Wooden Products, Chemicals, Construction, Transportation, Retail Trade and Food Products, whose collective agreements were signed in 2005, and Telecommunication, with agreements reached in 2006. 
Exposure to the reform of apprenticeship contracts occurred mostly through firms geographical location due to the staggered adoption of regional regulations implementing the national legislation. The first regulations were introduced in Emilia-Romagna and Tuscany in 2005, followed by Friuli, Marche, Sardinia and the autonomous province of Bolzano in 2006 and by Lazio in 2007. Other regions (Piedmont, Lombardy, Umbria, Abruzzo, Campania, Veneto, Liguria, Marche, Lazio) introduced experimental regulations only in some sectors (such as Retail Trade, Banking and Hotel and Restaurants), therefore we include firms operating in those sectors and in those regions in the treatment group. Finally, as explained in Section 2, Law 80/2005 allowed the possibility to use the new contracts to firms in sectors that would have reached national agreements afterwards, and we also include these firms in the treatment group.

In Table 2 we provide a description of the data. We begin by grouping firms on the basis of their exposures to the reforms, distinguishing never treated firms from firms treated by the apprenticeship contract reform and those exposed to the reform of fixed-term contracts. Since a firm may be exposed to both reforms, the sum of the numbers in the three groups exceed the number in the full sample. There are no firms in the treatment group in 2004. The number of firms treated by the reform of apprenticeship contracts is relatively small in 2005 (when only two regions adopted the regulations, while some others introduced experimental regulations in some sectors) but grows considerably in 2006 as a consequence of the adoption of regulations by several more regions and of Law 80/2005 which allowed the use of the new contracts in additional sectors. The number of treated firms still grows in 2007 as a consequence of Lazio joining the group of regions issuing regulations. Exposure to the reform of the fixed-term contracts follows a different pattern: most firms enter the treatment groups in 2005, and the remaining few cases which join in 2006 are firms in Telecommunication. We compute firm 
size including also external staff (agency workers and collaborators) and obtain an average of about 200 workers (about 190 if excluding external staff), slightly higher among the never treated and lower among firms in the treatment group of the apprenticeship reform. The workforce composition is rather stable across groups, but treated firms tend to have a higher share of fixed-term and apprenticeship contracts, whereas never treated ones use relatively more collaboration contracts. Considering job turnover (computed as the mean absolute employment change), we can observe that there are essentially no differences across treatment groups: average turnover is about $11 \%$ in each group, virtually identical to the values reported by Autor et al. (2007) on plant-level data. The proportion of positive changes is 44\%, about $5 \%$ points lower than the figures of Autor et al. (2007), and there is little variation across the groups. The geographical distribution of the firms reflects the well known regional heterogeneity of economic activity in Italy, with most firms located in the North-west and the North-east. The largest share of firms in the sample operates in Manufacturing. The sectorial distribution by treatment status is sparse in the case of fixed-term contract reform because only firms in some sectors were treated.

\section{Estimation Framework}

We are interested in assessing the impact of the two reforms on measures of job turnover, production inputs and productivity. As documented in the previous sections, we can exploit the differential variation in firms' exposure to the reforms across regions and sectors over time in a difference-in differences set-up. Let $d_{i t}^{F}$ be a dummy capturing the exposure of firm $i$ in time $t$ to the reform of fixedterm contracts, and $d_{i t}^{A}$ a dummy capturing the exposure of firm $i$ in time $t$ to the reform of apprenticeship contracts, with $t=2004, \ldots, 2007$. In order to ensure that 
our comparisons across treatment groups over time do not reflect group-specific characteristics, we control for time, region and sector fixed effects, plus regionspecific and sector-specific time trends. The latter require that identification comes from the discontinuity surrounding the passage of the reforms. These specifications can provide reassurance that estimated reforms effects are not reflecting smoothlytrending omitted variables that are potentially correlated with the adoption of the reforms. Our main estimating equation takes the following form:

$$
Y_{i t}=\gamma_{F} d_{i t}^{F}+\gamma_{A} d_{i t}^{A}+\delta_{t}+\sum_{s}\left(\theta_{s}+\lambda_{s} t\right) Z_{i}^{s}+\sum_{r}\left(\theta_{r}+\lambda_{r} t\right) Z_{i}^{r}+\beta^{\prime} X_{i t}+\varepsilon_{i t}
$$

where $Y$ is an outcome measure, the $\gamma$ coefficients measure the effects of the two reforms on the outcome, $\delta_{t}$ is a time fixed effect, $Z_{i}^{r}$ and $Z_{i}^{s}$ are dummy variables for regions and sectors, so that the $\theta$ coefficients capture regional $(r)$ and sectorial $(s)$ fixed effects, while the $\lambda$ coefficients capture region- and sectorspecific time trends, $X_{i t}$ is a vector of controls and $\varepsilon_{i t}$ is an error term. Whenever the outcome of interest is measured in levels (employment, capital, investment, skill composition and productivity) we include firms fixed effects, while in case of variables derived from differencing levels, like job turnover and employment growth, we do not include firm fixed effects. We use throughout a robust variance estimator to account for the presence of repeated observations on the same firms over time.

We start by looking at job flows as the outcome of interest. Specifically, we consider the year-to-year job turnover defined as in Davis et al. (1996) and Autor et al. (2007) : JT $T_{i t}=\frac{|E i t-E i t-1|}{\frac{1}{2}(E i t+E i t-1)}$ where $E_{i t}$ is firm $i$ employment in year $t$. This measure accounts for the absolute year-to-year employment change by recording annual net employment flows. Since we have detailed information on the type of 
employment contracts, we are able to estimate the reforms' impact on employment flows considering either total employment and employment in each contract type. This exercise enables an indirect assessment of the degree of substitutability between different types of employment contracts. In other words, the effectiveness of reforms in one type of employment contract depends on the extent to which firms are able to substitute between contract types. Estimating the impact of reforming one type of contract on job flows of another contract type is a way to assess the existence of substitution effects across contracts.

Next, our investigation will proceed by applying the estimating framework of equation (1) to other margins of firms decision, namely employment levels (overall and by contract type), capital (total and per worker), investments (total and per worker) and the skill ratio defined as the ratio between non-manual and manual workers in the firm. Applying equation (1) to this set of outcomes will offer a rather complete picture of the effects of the two reforms on firms production choices. Finally, we will focus our attention on the results of firms activity, namely on various measures of productivity. Specifically we will consider value added per worker, revenues per worker and total factor productivity.

\subsection{Assessing the Validity of Identification}

The validity of the identification of (1) rests on the exogeneity of the reforms. In the ideal case, the reform adoption decisions (by the regions and the sectorial bargaining rounds) would be independent random events that varied in timing and had no spillover effects to non-adopting regions or sectors. While firm migration across sectors and regions to take advantage of the rules is highly unlikely, one possible concern is that the regions and/or sectors which had higher or lower than average employment growth in temporary contracts or productivity were also the same to adopt the reforms of the apprenticeship contract or of the fixed-term 
contract. $^{7}$

To dispel this doubt we use external data taken from the Italian Labour Force Survey (LFS) for employment and National Accounts for hourly productivity between 1996 and 2007. We cannot use our firm-level data because we need to observe several years of data prior to the reforms to control for pre-dating trends in temporary employment and productivity, whereas in the Excelsior-ASIA data 2004 is the only pre-reform year. For information on temporary contracts we use LFS data which, although based on individuals and not on firms, are a representative sample of the Italian labour market. The top panel of Figure 1 compares the log employment in all types of temporary contracts in the regions adopting the apprenticeship contract reform (treated sample) and in the non-adopting regions (control sample). ${ }^{8}$ The bottom panel does the same for adopting and non-adopting sectors of the fixed-term contract reform. Both panels show a similar movement in the two series before the adoption of the two reforms in 2005 thus supporting the validity of our identification strategy which is based on the assumption that the outcomes of interest would have otherwise evolved similarly in adopting and non-adopting regions and sectors.

To further prove that trends in temporary employment do not predict the adop-

\footnotetext{
${ }^{7}$ One additional channel for spillover effects is the mobility of individuals, rather than firms, to adopting sectors. We address this possibility using LFS longitudinal data. We build a measure of worker mobility with an indicator dummy which takes the value one if individuals move from control to treated sectors. We run regressions of this mobility measure on age, sex, education and regional controls plus year dummies. We find that coefficients associated with year dummies before and after the reform are not significantly different. The hypothesis of joint equality of coefficients on time dummies before and after the reform cannot be rejected at usual levels of confidence $(\mathrm{P}$-value $=0.64)$.

${ }^{8}$ Data are indexed to 1996 to ease comparability with the National Accounts figures on productivity which are distributed by the National Statistical Institute in indexed form. The graph is based on regional-level averages and therefore neglects sectorial variation in the implementation of the apprenticeship contracts reform. As explained in Section 2, sectorial variation was mostly due to Law 80/2005, which is unlikely to reflect endogenous responses of sectors to changing economic conditions. Similar remarks apply to the regression of Table 3.
} 
tion of the reforms, we regress the two treatment dummies defined at the sectorial level (for the fixed-term contract reform) or regional level (for the apprenticeship contract reform) on leads and lags of log employment in temporary contracts. The coefficients on the lags are relative to the period five years prior to the reform, and their pattern indicates whether the coefficients associated with the reform in equation (1) are consistent with a causal interpretation. In particular, we would be concerned if there are large and statistically significant coefficients on the lag indicators, regardless of whether they are positive or negative. The first two columns of Table 3 show the effect of log temporary employment on the adoption of the apprenticeship contract reform. The results show that past temporary employment has no significant effect on the adoption of the reform. In the same way the third and fourth columns show that past temporary employment has no effect on the adoption of the fixed-term contract reform.

In Figure 2 and in Table 4 we repeat the same exercise using data on value added per hour of work. Hourly productivity, derived from National Accounts, is averaged across treated and control sectors and regions using employment weights. Also in this case the evidence shows that there are no differential trends between treated and control groups nor any systematically significant association between reform adoption and leads and lags of productivity. Overall, the evidence from both figures and tables are consistent with a causal interpretation of the effects of the reforms that we are going to discuss in the next section.

\section{Results}

We begin by assessing the impact of the two reforms on the level of job reallocation. If the reforms decreased the costs of using certain types of temporary contracts, then we should expect an increase in the hiring and dismissal of workers with 
those same contracts, which in turn should result in an increase of employment fluctuations.

We next consider the effects of the reforms on firms' employment, both at the aggregate level and by contract types. We also investigate the effects of the reforms on some other margins of firm adjustment along which theory does not give clear predictions and prior research has obtained mixed results: capital (total and per worker), investment (total and per worker) and the skill mix, defined as the ratio between non-manual and manual workers in the firm.

After considering the impact of the reform on various dimensions of inputs to the production process, our analysis moves on to consider effects on productivity, looking at both labour productivity and total factor productivity (TFP). Finally, we provide evidence on the interplay between firms' production function and the various forms of labour contracts by estimating the elasticity of substitution among temporary employment contracts and between these and permanent contracts.

\subsection{Job Reallocation}

Table 5 provides results on job turnover. Panel (A) of the Table considers overall job turnover. The reform of apprenticeship contracts had a positive effect on apprentices' turnover, producing a statistically significant increase of about 3 percentage points (p.p.). The reform, on the other hand, had no significant effects on the use of other types of employment contracts, nor on turnover in total employment. The reform of fixed-term contracts had a positive effect on job reallocation within this type of employment contracts, which is similar in size to the effect of the apprenticeship contract reform on turnover of apprentices, 3 p.p.. Moreover, a somewhat unexpected and smaller effect of this latter reform can be observed on turnover in permanent contracts, 1 p.p.. We can also observe a negative significant effect on total employment turnover, although of limited size, 0.5 p.p.. 
The measures of turnover cannot distinguish whether the effects come from more hiring or more firing. We provide insights on this point by looking at the

effects of reforms on employment growth (defined as $\log E_{i t}-\log E_{i t-1}$ ) in Panel (B) of the same table. The results confirm the positive effects of the reform of apprenticeship contracts, i.e. firms exposed to the reform increased their use of the new apprenticeship contract. There is also a negative and significant coefficient estimated on the growth rate of collaborator workers which is consistent with the idea that firms used the new apprenticeship contracts for substituting external workforce with workers employed by the firm. The reform of fixed-term contracts, instead, had no significant effect on the growth rate of fixed-term contracts and at the same time had negative significant effects on the use of all other contracts except for collaborators. Both these results suggest that this reform was not successful in stimulating fixed-term employment and rather induced more use of external staff. This substitution across contract types may have been the unintended consequence of the reform, possibly a symptom of the increased uncertainty on the applicability of fixed-term contracts.

\subsection{Robustness}

In Table 6 we assess the robustness of our findings on job turnover. Some regions experimented the apprenticeship contract reform in some sectors in 2005 and one may be concerned that the choice of sectors is not random. To address this concern in Panel (A) we drop from the analysis all observations of firms exposed to the regional-sectorial experimental projects. In the case of the fixed-term contract reform, two sectors -Banking and Metal Manufacturing - renewed the collective agreements during the period 2004-2007 but decided to postpone the implementation of the new fixed-term contract to a successive agreement that took place after the period covered by our analysis. To assess the robustness of the results, in 
Panel (B) we excluded firms in Banking and Metal Manufacturing from the analysis. Finally, in Panel (C) we augment the specification of equation (1) by adding the interaction of the two reforms. This will tell us whether the effectiveness of one reform depends on the presence of the other. ${ }^{9}$

The results in Panel (A) of Table 6 show that the analysis is robust to the exclusion of those sectors that were subject to the regional experimentation of the apprenticeship contract reform. The only notable change with respect to the benchmark of Table 5 is a marginal reduction in size and significance of the effect of the apprenticeship contract reform on turnover of apprentices (from 3.1 p.p. to 2.5 p.p.).

In Panel (B) the results are generally robust to the exclusion of the Banking and Metal Manufacturing sectors. The results in Column (4) show that the coefficient of the apprenticeship contract reform on the turnover of apprentices loses size and significance. Note however that in this panel we test the robustness to the fixedterm contract reform and the coefficient on apprenticeship contract reform is not the object of the sensitivity analysis. The coefficient drops in size and significance because we excluded from the sample firms in Banking and Metal Manufacturing and these same two sectors are part of the treatment group of the apprenticeship contract reform.

Results from Panel (C) also point towards the robustness of the evidence when we add the interaction term. We note that the negative effect of the fixed-term contract reform on total employment turnover is mitigated when firms are also exposed to the reform of the apprenticeship contract, see the positive coefficient associated with the interaction term. In Column (4) we observe that the results

\footnotetext{
${ }^{9}$ In Cappellari et al. (2011) we also assessed robustness to: 1) excluding firms that displayed very low or very high levels of year to year change in capital levels; 2) controlling for firms characteristics in terms of capital levels, value added and the skill mix; 3) adding firm fixed effects. In all cases the evidence was generally corroborative of the results discussed in the main text.
} 
are robust i.e. the coefficient on apprenticeship contract reform keeps size and significance. The most notable change is in Column (2) and (3) where the positive effect of the fixed-term contract reform is larger in those firms that are exposed to both reforms.

\subsection{Employment Levels}

The overall effect of the increase in turnover on the level of employment is theoretically ambiguous because a higher turnover may imply a higher or lower net employment. To understand the employment effects of the new legislation, in Table 7 we estimate regressions for firms log employment. We consider both aggregate employment and employment in each type of contract. ${ }^{10}$ In Panel (A) all regressions include firms fixed effects. The apprenticeship contract reform had a positive effect on the net employment of apprentices: firms exposed to this reform experienced an increase in the level of apprenticeship employment of 5.2 p.p.. The other effect of this reform is a reduction in the level of employment of collaborators, minus 6.5 p.p.. This is in line with the findings on employment growth as firms appear to have used the reform to hire apprentices and reduce the use of external workforce. Often collaborator workers are young individuals in the same age range covered by apprenticeship contracts, 15 to 30, and it may well be that firms consider workers on these contracts as substitutes for apprentices. A reason to move away from external workers may be their lower attachment to the firm and higher turnover costs.

Similar positive employment effects, instead, cannot be found for the reform of fixed-term contracts. In this case, there are no significant effects on employment of either permanent, fixed-term employees or apprentices, whereas there are effects

\footnotetext{
${ }^{10}$ We experimented using Tobit regressions to account for censoring at zero in the employment of some type of contracts. The results (not reported) confirm the robustness of our benchmark employment regression.
} 
on the levels of agency and collaborator workers that go in opposite directions with respect to each other. The overall employment effect is small (0.9 p.p.) and negative. This evidence confirms that the reform of fixed-term employment has not been successful in promoting the use of this type of contracts by firms.

In order to ease comparability with the results on job flows in Table 5 which did not include firm fixed effects, in Panel (B) we report results without firm fixed effects. Results on apprenticeship contract reform are in line with those obtained with firm fixed effects in Panel (A), the only exception being a significant negative effect on the employment of agency workers, which reinforces the interpretation based on substitution between external and internal staff. In the case of the fixed-term contract reform, some coefficients that where small and or statistically insignificant in the regression with firm fixed effects, now become positive, sizeable and significant (effects on total, permanent and fixed-term employment). This reflects time-invariant unobserved heterogeneity between treated and control firms.

\subsection{Investment, Capital and Skill Ratio}

We now explore the consequences of the reforms on other margins of firms' adjustment such as capital, capital-labour substitution and investments: if reforms make the use of temporary workers easier and facilitate adjustment firms may substitute out of capital with new (temporary) workers. Alternatively firms may vary their skill ratio: this may happen if workers with certain skills tend to be concentrated in specific types of contracts, or if the easing of temporary contracts make the use of skills more or less intensive. A higher capital-labour ratio or a higher skill mix should also improve productivity.

In Table 8 Columns (1) and (2) we look at the effects of the reforms on log capital and the log capital-labour ratio. The reform of fixed-term contracts had a negative effect on firms' capital and the capital-labour ratio, which decreased by 
2.6 and 1.6 p.p. In terms of the literature discussed in Section 2, the substitution effect between capital and labour prevailed over the 'hold up' effect. In Columns (3) and (4) we consider investment and investment per worker: since in the data we have information on net capital $K$, we define investment as $I_{t}=K_{t}-K_{t-1}$, i.e. we do not apply any depreciation rate. As is the case with capital, the reform of fixed-term contracts impacted negatively on investment, although standard errors are relatively large and the estimated coefficients not statistically significant at conventional levels. These effects of the fixed-term contract reform contrast with the ones from the reform of apprenticeship contracts. In this case estimated coefficients are smaller in size and never significant from a statistical point of view.

The last set of results in Table 8 (Column 5) refers to a different substitution margin between skilled and unskilled workers. We find no effects of the two reforms on the skill ratio. This result may be explained because temporary contracts are popular among both white and blue collars, particularly of young age.

\subsection{Productivity Measures}

We now turn in Table 9 to productivity measures, which possibly represent the most relevant benchmark to measure the economic implications of institutional changes. We consider three different measures of productivity. The first is labour productivity defined as real value added per worker. The second focuses on firms sales and is defined as revenues per worker. Finally, we partial out the contribution of physical capital and build a measure of TFP as the residual of a regression of $\log$ value added on log capital and log employment. ${ }^{11}$

\footnotetext{
${ }^{11}$ We experimented using as denominator (for labour productivity) or control (for TFP) measures of employment that exclude external staff i.e. agency workers and collaborators. Dey et al. (2012) discuss the issue of computing productivity across sectors when the sectorial affiliation of external staff is different from the one of the firm, e.g. service sector for external staff and manufacturing for the firm. We obtained virtually identical results in the two cases, and we present only those obtained using the overall number of workers.
} 
Panel (A) of Table 9 shows that the apprenticeship contract reform has had a positive and significant impact on all measures of productivity, between 0.9 p.p. and 1.6 p.p. in the case of sales per worker and TFP. Results on the fixed-term contract reform tell a completely different story, all coefficients being negative, sizeable (between 2.4 and 3.5 p.p.) and statistically significant.

Taken together with the results on employment turnover and employment levels, the productivity effects confirm that while the apprenticeship reform has been successful, the reform of fixed-term contracts generated effects that were opposite to expectations. To further assess the causal interpretation of our findings, in Panel (B) of Table 9 we use lagged values of the treatment indicators in place of current values. In this way we avoid picking up any simultaneity between institutional changes at the sectorial or regional level and productivity growth. Results are robust to the use of lagged treatment indicators, the only coefficient which loses significance is the one for the effect of the apprenticeship reform on revenues per worker.

A possible interpretation of these results is the following. The increase in the number of apprentices occurred through substitution of external staff, mainly collaboration workers. The rise in productivity that we observe is likely to reflect a compositional shift in labour quality because our labour productivity measures do not adjust for the quality of labour inputs. To the extent that external collaborators have lower attachment to the firm and exert lower effort, the reform of apprenticeship contracts may have induced firms to shed this relatively unproductive labour in exchange for more motivated apprentices. Although we do not have direct evidence of this, higher workers' effort is plausibly the mechanism that may have increased labour productivity after the reform (Riphahn and Engellandt, 2005; Dolado et al., 2012).

The reform of fixed-term contracts had the opposite effect on productivity. In 
this case, firms exposed to the reform were induced to use more extensively external collaborators which reduced productivity. In parallel, these firms have also reduced capital intensity, which may also have induced the observed productivity decline.

We further assess the result on productivity in Table 10. We perform the same sensitivity checks as we did in Table 6 for turnover. Namely we exclude firms exposed to regional-sectorial experimentations in Panel (A); we exclude firms in Banking and Metal Manufacturing in Panel (B); we add the interaction term of the two reforms in Panel (C). All results are confirmed in Panel (A). In Panel (B) the effects of the fixed-term contract reform on productivity are confirmed. The effects of the apprenticeship contract reform are much weaker but as explained above eliminating firms in Banking and Metal Manufacturing is meant to assess the robustness of the fixed-term contract reform and not of the apprenticeship contract reform. The weaker effects are explained by the fact that the these two sectors are treated by the apprenticeship reform. Finally Panel (C) shows that results are robust to the inclusion of the interaction term. The positive effect of the apprenticeship contract reform on measures of productivity is confirmed. The negative effect of fixed-term contract reform is more evident in those firms that are exposed to both reforms.

\subsection{Substitution Effects}

The reform of apprenticeship contracts induced substitution of external staff with apprentices. The reform of fixed-term contracts increased job flows of fixed-term contracts, reduced significantly total turnover and favoured the employment of external collaborators. These results suggest substitutability not only between permanent and temporary contracts but also among temporary contracts of various types, which is something that has always been known among employers but has never been investigated by economists. While in the literature there are many 
papers on substitution elasticities across factors of production, there are no studies on the substitution across different types of temporary contracts. ${ }^{12}$

In order to provide a direct assessment of substitution effects across different types of contracts, we estimate the parameters of a production function in capital and labour. We allow labour inputs to differ according to the contract type, distinguishing between permanent and temporary employment contracts and, within temporary contracts, among the four types of temporary contracts that are available to firms. In other words we estimate a simple production function where the four types of temporary contracts are partial substitutes and the entire group of temporary contracts is substitutable for permanent contracts. We model the substitution across different types of labour contracts using a nested CES technology:

$$
Q_{i t}=K_{i t}^{\alpha}\left[L_{p i t}^{\sigma}+\left(\Sigma_{\tau} L_{\tau i t}^{\rho}\right)^{\frac{\sigma}{\rho}}\right]^{\frac{(1-\alpha)}{\sigma}}
$$

where $Q$ is the value added, $K$ is capital, $L_{p}$ is permanent labour and $L_{\tau}$ represents four types of flexible labour (agency workers, collaborators, apprentices and fixedterm workers). Using this nested CES specification, parameters $\sigma$ and $\rho$ govern the substitution process between labour inputs. In particular $\eta_{\rho}=\frac{1}{1-\rho}$ defines the substitution elasticity between varieties of temporary labour, while $\eta_{\sigma}=\frac{1}{1-\sigma}$ defines the substitution elasticity between permanent and temporary labour. ${ }^{13}$

Table 11 shows that the elasticity of substitution between various types of temporary contracts is high and significant, higher than the elasticity of substitution

\footnotetext{
${ }^{12}$ The most famous studies which look at labour factors of different types, typically different education levels, find elasticities of substitution between college-educated and high-school educated workers in the US in the range of 0.5 to 2.5. In their seminal paper Katz and Murphy (1992) find a value of 1.4 .

${ }^{13}$ Estimates of substitution elasticities are typically obtained using wage bill shares and the conditional factor demand also includes changes in prices and quantities of other omitted inputs such as capital and energy. We do not have information on relative prices of all inputs (i.e. types of temporary contracts) but we allow for substitution possibilities across other inputs estimating elasticities in a CES function which includes capital.
} 
between permanent contracts and temporary contracts. Pooling all years between 2004 and 2007, the elasticity of substitution between temporary contracts is 1.4 (with some variation across years) while the elasticity of substitution between permanent and temporary contracts is stable at around unity. In year 2007 the estimated elasticity of substitution between the four types of temporary contracts is not statistically significant. The elasticity of 1.4 is high and means that small changes in relative prices between different types of contracts yield big changes in relative quantities. This elasticity is higher than the elasticity between temporary and permanent contracts which have very different characteristics and presumably are harder to substitute.

\section{Discussion and Conclusion}

The overall picture emerging from our analysis shows that the reform of apprenticeship contracts has been successful because it increased the turnover and the net employment of apprentice workers. These results suggest that the reform actually reduced the cost of apprenticeship contracts and firms were encouraged to substitute external temporary staff with apprentices. Although the capital-labour ratio remained unaffected, the reform increased labour productivity possibly through one of the mechanisms suggested in the literature, for example increasing average worker effort through the employment of more motivated workers (i.e. apprentices facing the prospects of training and wage growth) to replace external less motivated staff. The reform of fixed-term contracts instead does not seem to have had the intended results: the reform reduced job turnover, reduced the capitallabour ratio and had a negative effect on productivity. By negatively affecting job reallocation and favoring the use of external collaborators, the reform has hampered the optimal allocation of resources and has consequently reduced the level 
of productivity.

There is one general lesson that can be drawn from this experience. A reform intended to ease the use of fixed-term contracts, was instead perceived by firms as a likely source of additional complex and time-consuming legal processes and eventually increased the expected labour cost. This happened because, in a country where labour courts have in general a restrictive reading of the norms, a more generic legislation had the effect of increasing uncertainty about the judges' interpretation of the norm. This effect is not dissimilar from the finding of Autor et al. (2007) on wrongful dismissal exceptions in the United States. In Autor et al. (2007) an increase in EPL costs is aggravated by the increase in uncertainty, while in our case the effects of a reform that liberalizes the use of fixed-term contracts are offset by the increase in uncertainty.

The crucial mechanism that made the reform of apprenticeship contracts successful and the reform of fixed-term contracts ineffective is the substitution within different types of temporary workers. While the reform of apprenticeship contracts reduced the use of external staff, the reform of fixed-term contracts generated the opposite effect. This interpretation is supported by estimates of high substitution elasticities across different types of temporary contracts. Nowadays policy makers in many countries are thinking of limiting the diffusion of temporary employment by limiting some specific type of temporary contracts that are deemed the most misused. These policies often do not predict the offsetting effects through firms' substitution towards other types of temporary contracts and the potential impact on productivity. The evidence provided in this paper may therefore be helpful in the policy debate. 


\section{References}

[1] Aimo, M. P. (2006). 'Il contratto a termine alla prova.' Lavoro e Diritto, vol. 2-3, pp. 459-494.

[2] Autor, D. H. (2003). 'Outsourcing at will: the contribution of unjust dismissal doctrine to the growth of employment outsourcing.' Journal of Labor Economics, vol. 21, pp. 1-42.

[3] Autor, D. H. and Houseman, S. N. (2010). 'Do temporary-help jobs improve labor market outcomes for low-skilled workers? evidence from "Work First".' American Economic Journal: Applied Economics, vol. 2, pp. 96-128.

[4] Autor, D. H., Kerr, W. R. and Kugler, A. D. (2007). 'Do employment protections reduce productivity? Evidence from U.S. states' ECONOMIC JOURNAL, vol. 117, pp. F189-271.

[5] Bartelsman, E. J. and Hinloopen, J. (2005). 'Unleashing animal spirits: ICT and economic growth'. In The Economics of the Digital Economy (eds. L. Soete and B. ter Weel), pp. 272-304. Cheltenham, U.K.: Edward Elgar Publishing.

[6] Bassanini, A., Nunziata, L. and Venn, D. (2009). 'Job protection legislation and productivity growth in OECD countries.' Economic Policy, vol. 24, pp. 349-402.

[7] Belot, M., Boone, J. and van Ours, J. C. (2007). 'Welfare effects of employment protection.' Economica, vol. 74, pp. 381-96.

[8] Bentolila, S. and Bertola, G. (1990). 'Firing costs and labor demand: how bad is eurosclerosis?' Review of Economic Studies, vol. 57, pp. 381-402. 
[9] Blanchard, O. J. and Landier, A. (2002). 'The perverse effects of partial labor market reform: fixed duration contracts in France' ECONOMIC JOURNAL, vol. 112, pp. F214-244.

[10] Boeri, T. (2011). 'Institutional reforms and dualism in European labor markets'. In Handbook of Labor Economics (eds. O. Ashenfelter and D. Card), Chapter 13, Volume 4B. Amsterdam and New York: North Holland.

[11] Boeri, T. and Garibaldi, P. (2007). 'Two-tier reforms of employment protection legislation: a honeymoon effect' ECONOMIC JOURNAL, vol. 117, pp. 357-385.

[12] Booth, A., Francesconi, M. and Frank, J. (2002). 'Temporary jobs: stepping stones or dead ends?' ECONOMIC JOURNAL, vol. 112, pp. F189-213.

[13] Cappellari, L., Dell'Aringa, C. and Leonardi, M. (2011). 'Temporary employment, job flows and productivity: a tale of two reforms.' CESifo working paper No. 3520 .

[14] Cahuc, P., Charlot, O. and Malherbet, F. (2012). 'Explaining the spread of temporary jobs and its impact on labor turnover.' IZA discussion paper No. 6365 .

[15] Cahuc, P. and Postel-Vinay, F. (2002). 'Temporary jobs, employment protection and labor market performance.' Labour Economics, vol. 9, pp. 63-91.

[16] Cingano, F., Leonardi, M., Messina, J. and Pica, G. (2010). 'The effect of employment protection legislation and financial market imperfections on investment: evidence from a firm-level panel of EU countries.' Economic Policy, vol. 25, pp. 117-163. 
[17] Davis, S., Haltiwanger, J. and Schuh, S. (1996). Job Creation and Job Destruction. Cambridge, MA: MIT Press.

[18] Dey, M., Houseman, S. and Polivka, A. (2012). 'Manufacturers outsourcing to staffing services.' Industrial and Labor Relations Review, forthcoming.

[19] Dolado, J. J., Garcìa-Serrano, C. and Jimeno, J. F. (2002). 'Drawing lessons from the boom of temporary jobs in Spain' ECONOMIC JOURNAL, vol. 112, pp. F270-295.

[20] Dolado, J. J., Ortigueira, S. and Stucchi, R. (2012). 'Does dual employment protection affect TFP?: Evidence from Spanish manufacturing firms.' CEPR discussion paper No. 8763.

[21] Garibaldi, P. and Violante, G. L. (2005). 'The employment effects of severance payments with wage rigidities' ECONOMIC JOURNAL, vol. 115, pp. 799832.

[22] Holmlund, B. and Storrie, D. (2002). 'Temporary work in turbulent times: the Swedish experience’ ECONOMIC JOURNAL, vol. 112, pp. F245-269.

[23] Houseman, S. N. (2001). 'Why employers use flexible staffing arrangements: evidence from an establishment survey.' Industrial and Labor Relations Review, vol. 55, pp. 149-170.

[24] Houseman, S. N., Kalleberg, A. and Erickcek, G. A. (2003). 'The role of temporary agency employment in tight labor markets.' Industrial and Labor Relations Review, vol. 57, pp 105-127.

[25] Ichino, A., Mealli, F. and Nannicini, T. (2008). 'From temporary help jobs to permanent employment: what can we learn from matching estimators and their sensitivity?' Journal of Applied Econometrics, vol. 23, pp. 305-327. 
[26] Ichino, A. and Riphahn, R. T. (2005). 'The effect of employment protection on worker effort: a comparison of absenteeism during and after probation.' Journal of the European Economic Association, vol. 3, pp. 120-143.

[27] ISFOL (2007). L'Apprendistato fra Regolamentazioni Regionali e Discipline Contrattuali, Monitoraggio sul 2005-2006. ISFOL: Rome.

[28] Katz, L. F. and Murphy, K. M. (1992). 'Changes in relative wages, 1963-87: supply and demand factors.' Quarterly Journal of Economics, vol. 107, pp. $35-78$.

[29] Koeniger, W. and Leonardi, M. (2007). 'Capital deepening and wage differentials: Germany versus U.S.' Economic Policy, vol. 22, pp. 71-116.

[30] Kvasnicka, M. (2009). 'Does temporary help work provide a stepping stone to regular employment?'. In Studies of Labor Market Intermediation (ed. D. Autor), pp. 335-372. Chicago: The University of Chicago Press.

[31] Lagos, R. (2006). 'A model of TFP.' Review of Economic Studies, vol. 73, pp. 983-1007.

[32] Lazear, E. (1990). 'Job security provisions and unemployment.' Quarterly Journal of Economics, vol. 55, pp. 699-726.

[33] Leonardi, M. and Pica, G. (2010). 'Who pays for it? The heterogenous wage effects of employment protection legislation.' IZA discussion paper No. 5335.

[34] Ljungqvist, L. (2002). 'How do layoff costs affect employment?' ECONOMIC JOURNAL, vol. 112, pp. F829-853.

[35] Martin, J. P. and Scarpetta, S. (2011). 'Setting it right: employment protection, labour reallocation and productivity.' IZA policy paper No. 27. 
[36] Micco, A. and Pagés, C. (2008). 'The economic effects of employment protection: evidence from international industry-level data.' Inter-American Development Bank working paper No. 495.

[37] Poschke, M. (2009). 'Employment protection, firm selection, and growth.' Journal of Monetary Economics, vol. 56, pp. 1074-1085.

[38] Riphahn, R. T. and Engellandt, A., (2005). 'Temporary contracts and employee effort.' Labour Economics, vol. 12, pp. 281-299.

[39] Tiraboschi, M. (2004). La Riforma Biagi del Mercato del Lavoro. Milano: Giuffrè Editore.

[40] Venn, D. (2009). 'Legislation, collective bargaining and enforcement: updating the OECD employment protection indicators.' OECD Social, Employment and Migration working papers No. 89.

[41] Wasmer, E. (2006). 'General versus specific skills in labour markets with search frictions and firing costs.' American Economic Review, vol. 96, pp. $811-31$. 

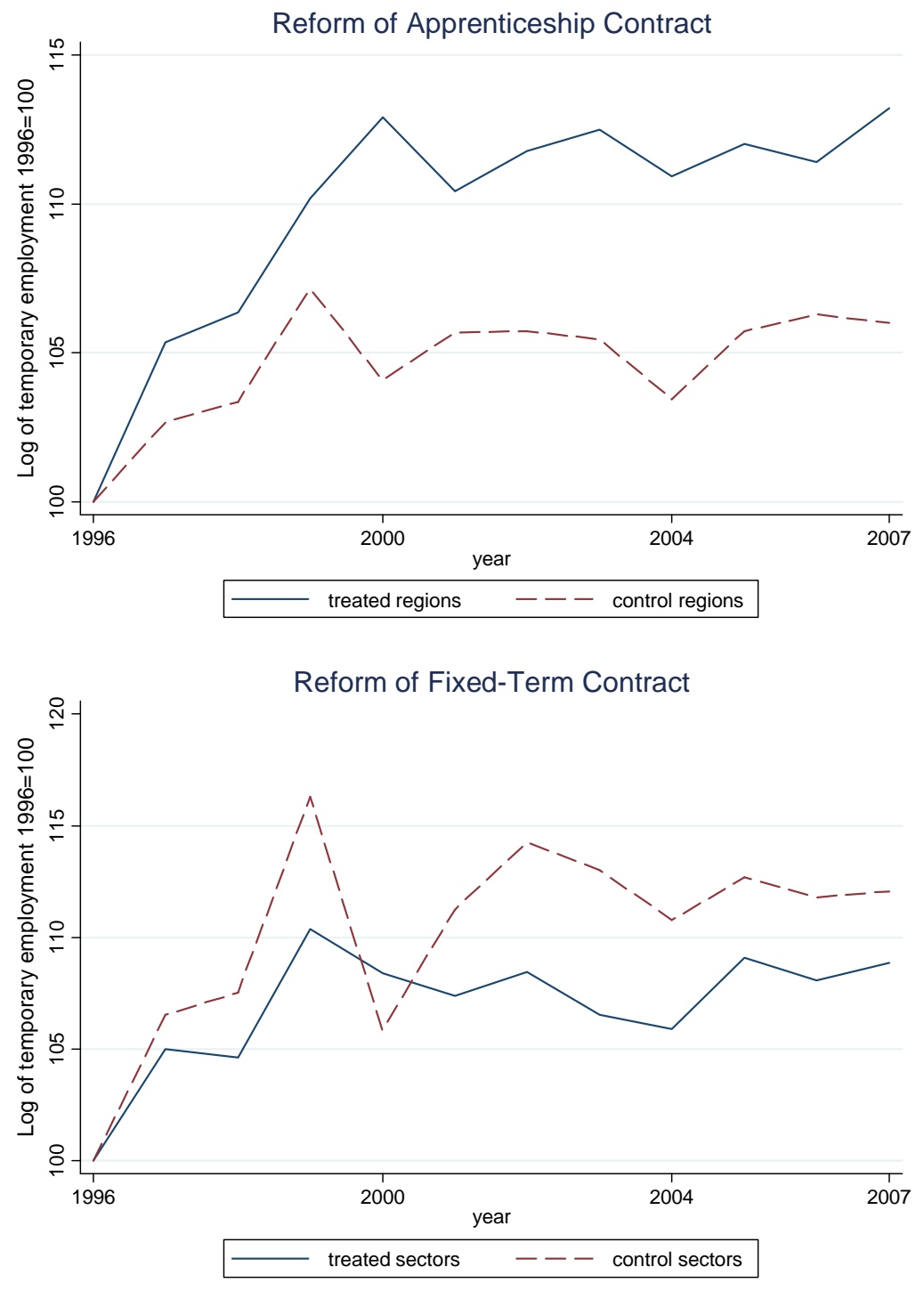

Fig. 1. Log Employment in Temporary Contracts in Treated and Control Groups 

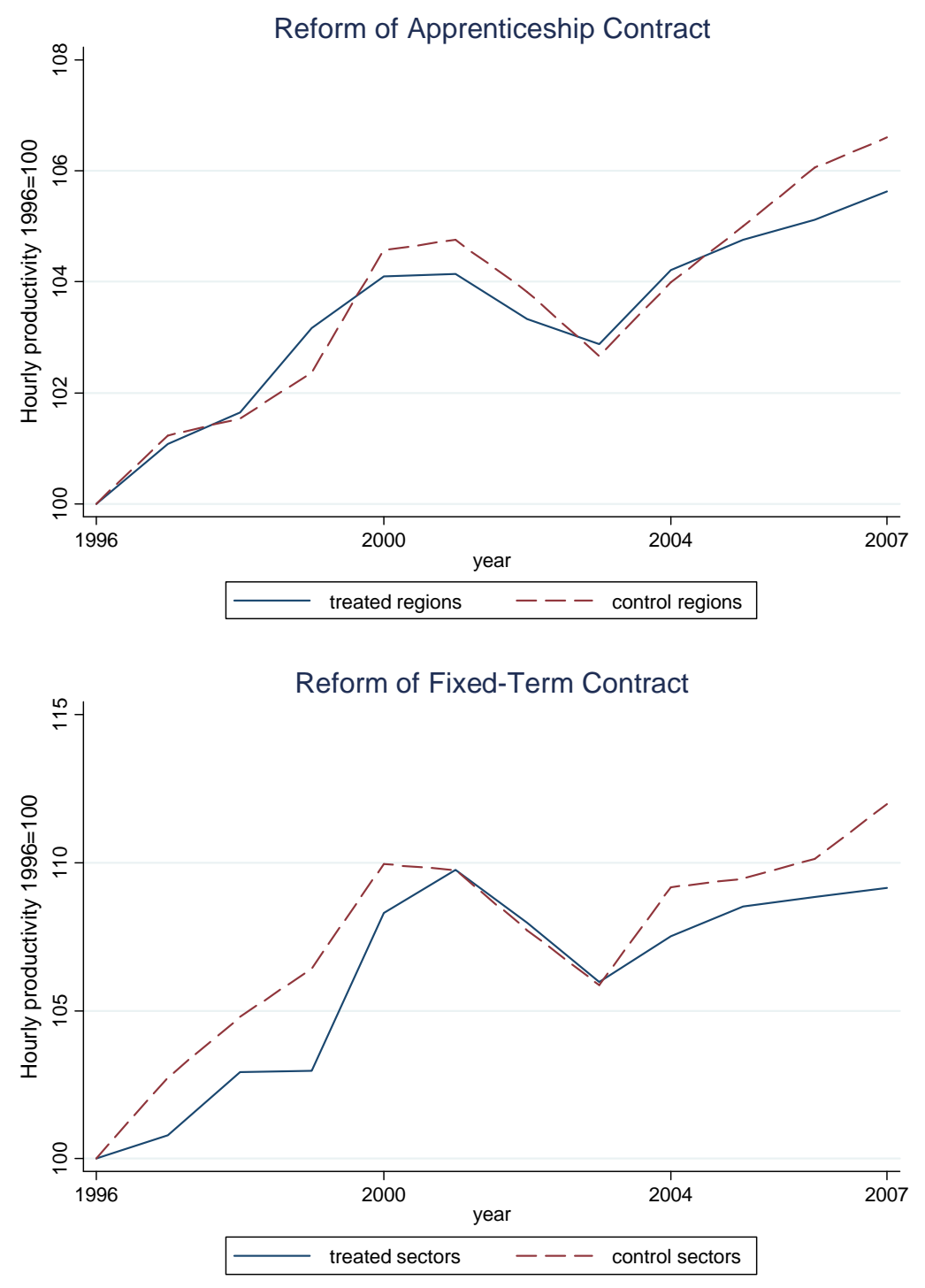

Fig. 2. Hourly Productivity in Treated and Control Groups 
Table 1: Employment and Social Security Contribution Wedge by Type of Contract Employment (in thousands) Social security contributions

$\begin{array}{lcc}\text { Permanent employees } & 14726 & 31 \\ \text { Fixed-term employees } & 1263 & 31 \\ \text { Apprenticeships } & 541 & 10 \\ \text { Agency workers } & 256 & 31 \\ \text { Collaborators } & 731 & 17\end{array}$

Note: Social security contributions as a percentage of gross earnings. Sources: Labour Force Survey (2011) and Social Security Institute. 
Table 2: Descriptive Statistics for Excelsior-Asia Firm Panel 2004-2007

\begin{tabular}{|c|c|c|c|c|}
\hline & Full sample & Never treated & $\begin{array}{c}\text { Reform of } \\
\text { apprenticeship }\end{array}$ & $\begin{array}{l}\text { Reform of } \\
\text { fixed term }\end{array}$ \\
\hline Number of observations & 53144 & 26182 & 24208 & 12994 \\
\hline 2004 & 13286 & 13286 & 0 & 0 \\
\hline 2005 & 13286 & 6922 & 3671 & 4316 \\
\hline 2006 & 13286 & 3170 & 10095 & 4339 \\
\hline 2007 & 13286 & 2804 & 10442 & 4339 \\
\hline Total employment & 203.21 & 210.95 & 193.90 & 201.30 \\
\hline$\%$ Permanent contracts & 88.11 & 87.92 & 88.05 & 88.76 \\
\hline$\%$ Fixed term contracts & 6.02 & 5.78 & 6.38 & 5.99 \\
\hline$\%$ Apprenticeships & 1.92 & 1.76 & 2.09 & 2.31 \\
\hline$\%$ Agency workers & 2.32 & 2.25 & 2.44 & 2.10 \\
\hline \% Collaborators & 2.11 & 2.57 & 1.69 & 1.48 \\
\hline$\%$ Blue collars & 60.85 & 60.09 & 61.12 & 60.32 \\
\hline$\%$ White collars & 37.56 & 38.24 & 37.38 & 38.13 \\
\hline$\%$ Managers & 1.59 & 1.67 & 1.50 & 1.55 \\
\hline Capital per capita $(€ 2004)$ & 63653.45 & 63367.87 & 64548.91 & 58655.62 \\
\hline Job turnover & 11.33 & 11.61 & 11.32 & 11.01 \\
\hline$\%$ Positive employment growth & 44.01 & 43.69 & 44.94 & 42.63 \\
\hline$\%$ Northwest & 36.84 & 44.01 & 28.46 & 35.17 \\
\hline$\%$ Northeast & 31.44 & 25.95 & 38.20 & 30.58 \\
\hline$\%$ Central & 18.40 & 15.06 & 22.60 & 19.76 \\
\hline$\%$ South & 13.32 & 14.98 & 10.74 & 14.49 \\
\hline$\%$ Extraction & 0.72 & 0.98 & 0.52 & \\
\hline$\%$ Manufacturing & 54.55 & 52.98 & 55.24 & 48.39 \\
\hline \% Energy & 0.69 & 0.85 & 0.60 & \\
\hline$\%$ Construction & 5.87 & 2.99 & 7.15 & 17.97 \\
\hline$\%$ Retail trade & 10.87 & 5.49 & 16.42 & 33.36 \\
\hline$\%$ Hotel and restaurants & 2.19 & 2.68 & 1.91 & \\
\hline$\%$ Transports and communication & 6.97 & 6.32 & 8.34 & 0.28 \\
\hline$\%$ Finance & 0.05 & 0.08 & 0.03 & \\
\hline$\%$ Real estate & 10.55 & 16.29 & 5.52 & \\
\hline$\%$ Private education & 0.47 & 0.80 & 0.17 & \\
\hline$\%$ Private health & 4.92 & 7.60 & 2.58 & \\
\hline$\%$ Other services & 2.14 & 2.94 & 1.52 & \\
\hline
\end{tabular}


Table 3: Reform Adoption and Trends in Temporary Employment

\begin{tabular}{|c|c|c|c|c|}
\hline & \multicolumn{2}{|c|}{$\begin{array}{l}\text { Dummy reform of } \\
\text { apprenticeship }\end{array}$} & \multicolumn{2}{|c|}{$\begin{array}{l}\text { Dummy reform of } \\
\text { fixed term }\end{array}$} \\
\hline & (1) & $(2)$ & (3) & (4) \\
\hline \multirow[t]{2}{*}{ Log temporary employment } & -0.0037 & -0.109 & -0.0572 & 0.480 \\
\hline & $(0.0668)$ & $(0.158)$ & $(0.175)$ & $(0.437)$ \\
\hline \multirow[t]{2}{*}{ Log temporary employment $\mathrm{t}-1$} & 0.0683 & -0.122 & 0.0117 & 0.568 \\
\hline & $(0.0741)$ & $(0.164)$ & $(0.131)$ & $(0.417)$ \\
\hline \multirow[t]{2}{*}{ Log temporary employment $\mathrm{t}-2$} & 0.0783 & -0.265 & -0.123 & 0.589 \\
\hline & $(0.0764)$ & $(0.179)$ & $(0.127)$ & $(0.423)$ \\
\hline \multirow[t]{2}{*}{ Log temporary employment t-3 } & 0.0240 & -0.242 & -0.139 & 0.464 \\
\hline & $(0.0719)$ & $(0.154)$ & $(0.129)$ & $(0.344)$ \\
\hline \multirow[t]{2}{*}{ Log temporary employment $\mathrm{t}-4$} & 0.0803 & -0.237 & 0.0215 & $0.460^{*}$ \\
\hline & $(0.0742)$ & $(0.152)$ & $(0.139)$ & $(0.258)$ \\
\hline \multirow[t]{2}{*}{ Log temporary employment t- 5} & 0.112 & -0.116 & -0.0479 & 0.338 \\
\hline & $(0.0709)$ & $(0.112)$ & $(0.117)$ & $(0.221)$ \\
\hline \multirow{2}{*}{ Log temporary employment $t+1$} & 0.0390 & -0.0381 & 0.0946 & 0.697 \\
\hline & $(0.0701)$ & $(0.138)$ & $(0.155)$ & $(0.456)$ \\
\hline \multirow[t]{2}{*}{ Log temporary employment $t+2$} & 0.0789 & -0.0348 & -0.0595 & 0.510 \\
\hline & $(0.0802)$ & $(0.134)$ & $(0.173)$ & $(0.404)$ \\
\hline \multirow[t]{2}{*}{ Constant } & -1.597 & 43.76 & 2.724 & 305.8 \\
\hline & $(1.323)$ & $(87.79)$ & $(1.892)$ & $(245.2)$ \\
\hline Region trends & NO & YES & $\mathrm{NO}$ & NO \\
\hline Sector trends & NO & NO & NO & YES \\
\hline Observations & 95 & 95 & 60 & 60 \\
\hline R-squared & 0.409 & 0.721 & 0.392 & 0.710 \\
\hline
\end{tabular}


Table 4: Reform Adoption and Trends in Hourly Productivity

\begin{tabular}{|c|c|c|c|c|}
\hline & \multicolumn{2}{|c|}{$\begin{array}{l}\text { Dummy reform of } \\
\text { apprenticeship }\end{array}$} & \multicolumn{2}{|c|}{$\begin{array}{l}\text { Dummy reform of } \\
\text { fixed term }\end{array}$} \\
\hline & (1) & $(2)$ & $(3)$ & $(4)$ \\
\hline \multirow[t]{2}{*}{ Hourly productivity } & 0.0094 & 0.0026 & 0.0036 & -0.0171 \\
\hline & $(0.0326)$ & $(0.0488)$ & $(0.0098)$ & $(0.0133)$ \\
\hline \multirow[t]{2}{*}{ Hourly productivity t- 1} & -0.0056 & -0.0210 & -0.0043 & -0.0083 \\
\hline & $(0.0353)$ & $(0.0571)$ & $(0.0095)$ & $(0.0131)$ \\
\hline \multirow[t]{2}{*}{ Hourly productivity t-2 } & -0.0182 & -0.0834 & 0.0068 & $-0.0243^{* *}$ \\
\hline & $(0.0302)$ & $(0.0550)$ & $(0.0092)$ & $(0.0112)$ \\
\hline \multirow[t]{2}{*}{ Hourly productivity t-3 } & 0.0244 & -0.0161 & -0.0003 & -0.0092 \\
\hline & $(0.0293)$ & $(0.0369)$ & $(0.0098)$ & $(0.0116)$ \\
\hline \multirow[t]{2}{*}{ Hourly productivity t-4 } & 0.0148 & 0.0182 & 0.0114 & 0.0021 \\
\hline & $(0.0314)$ & $(0.0355)$ & $(0.0093)$ & $(0.0089)$ \\
\hline \multirow[t]{2}{*}{ Hourly productivity t- 5} & -0.0097 & 0.0388 & -0.0012 & 0.0135 \\
\hline & $(0.0286)$ & $(0.0376)$ & $(0.0075)$ & $(0.0094)$ \\
\hline \multirow[t]{2}{*}{ Hourly productivity $t+1$} & 0.0240 & 0.0258 & 0.0027 & -0.0185 \\
\hline & $(0.0333)$ & $(0.0406)$ & $(0.0107)$ & $(0.0124)$ \\
\hline \multirow[t]{2}{*}{ Hourly productivity $t+2$} & 0.0204 & -0.0211 & -0.0133 & -0.0154 \\
\hline & $(0.0314)$ & $(0.0482)$ & $(0.0093)$ & $(0.0107)$ \\
\hline \multirow[t]{2}{*}{ Constant } & -6.381 & 44.65 & -0.767 & -633.6 \\
\hline & $(8.219)$ & $(366.1)$ & $(0.909)$ & $(646.1)$ \\
\hline Region trends & NO & YES & NO & NO \\
\hline Sector trends & NO & NO & NO & YES \\
\hline Observations & 95 & 95 & 140 & 140 \\
\hline R-squared & 0.490 & 0.762 & 0.331 & 0.660 \\
\hline
\end{tabular}

Notes: Source National Accounts 1996-2007 value added per hour worked by region (reform of apprenticeship contracts) and by 2-digit sector (reform of fixed term contracts). Dependent variable is reform dummy, additional controls include year dummies, region dummies (columns 1 and 2) and sector dummies (columns 3 and 4). Regressions weighted by employment. Standard errors in parentheses $* * * \mathrm{p}<0.01,{ }^{* *} \mathrm{p}<0.05,{ }^{*} \mathrm{p}<0.1$. 
Table 5: The Effect of Reforms on Job Reallocation and Employment Growth

\begin{tabular}{|c|c|c|c|c|c|c|}
\hline & $\begin{array}{c}\text { Total } \\
\text { employment } \\
\text { (1) }\end{array}$ & $\begin{array}{c}\text { Permanent } \\
\text { contracts } \\
(2)\end{array}$ & $\begin{array}{c}\text { Fixed term } \\
\text { contracts } \\
(3)\end{array}$ & Apprenticeships & $\begin{array}{c}\text { Agency } \\
\text { workers } \\
(5)\end{array}$ & Collaborators \\
\hline \multicolumn{7}{|c|}{ Panel A: Job Turnover } \\
\hline Reform of Apprenticeship & -0.0020 & 0.0021 & -0.0022 & $0.0313^{* *}$ & -0.0094 & -0.0230 \\
\hline & $(0.0028)$ & $(0.0049)$ & $(0.0149)$ & $(0.0147)$ & $(0.0151)$ & $(0.0163)$ \\
\hline \multirow[t]{2}{*}{ Reform of Fixed term } & $-0.0054^{* *}$ & $0.0119^{* *}$ & $0.0309^{* *}$ & -0.0134 & -0.0040 & 0.0220 \\
\hline & $(0.0023)$ & $(0.0050)$ & $(0.0146)$ & $(0.0150)$ & $(0.0157)$ & $(0.0160)$ \\
\hline \multirow[t]{2}{*}{ Constant } & $0.114^{* * *}$ & $0.113^{* * *}$ & $0.505^{* * *}$ & $0.259 * * *$ & $0.225^{* * *}$ & $0.498^{* * *}$ \\
\hline & $(0.0146)$ & $(0.0248)$ & $(0.0805)$ & $(0.0673)$ & $(0.0549)$ & $(0.0830)$ \\
\hline R-squared & 0.018 & 0.018 & 0.004 & 0.022 & 0.053 & 0.014 \\
\hline \multicolumn{7}{|c|}{ Panel B: Employment Growth } \\
\hline \multirow[t]{2}{*}{ Reform of Apprenticeship } & 0.0034 & 0.0038 & -0.0048 & $0.0161^{* * *}$ & 0.0043 & $-0.0109 * *$ \\
\hline & $(0.0035)$ & $(0.0059)$ & $(0.0098)$ & $(0.0049)$ & $(0.0073)$ & $(0.0054)$ \\
\hline \multirow[t]{2}{*}{ Reform of Fixed term } & $-0.0093^{* * *}$ & $-0.0135 * * *$ & 0.0054 & $-0.0087^{* *}$ & $-0.0199 * * *$ & $0.0101^{* *}$ \\
\hline & $(0.0026)$ & $(0.0032)$ & $(0.0071)$ & $(0.0041)$ & $(0.0060)$ & $(0.0042)$ \\
\hline \multirow[t]{2}{*}{ Constant } & -0.0077 & -0.0003 & 0.0389 & -0.0064 & -0.0304 & 0.0115 \\
\hline & $(0.0229)$ & $(0.0263)$ & $(0.0426)$ & $(0.0257)$ & $(0.0236)$ & $(0.0227)$ \\
\hline R-squared & 0.008 & 0.004 & 0.002 & 0.003 & 0.003 & 0.002 \\
\hline
\end{tabular}

text. All regressions include controls for time, region and sector dummies and region- and sector-specific trends.

Robust standard errors in parentheses are clustered at the firm level $* * * \mathrm{p}<0.01,{ }^{* *} \mathrm{p}<0.05,{ }^{*} \mathrm{p}<0.1$. 
Table 6: Robustness Checks on Job Turnover

\begin{tabular}{|c|c|c|c|c|c|c|}
\hline & $\begin{array}{c}\text { Total } \\
\text { employment } \\
\text { (1) }\end{array}$ & $\begin{array}{c}\text { Permanent } \\
\text { contracts } \\
(2)\end{array}$ & $\begin{array}{c}\text { Fixed term } \\
\text { contracts } \\
(3)\end{array}$ & Apprenticeships & $\begin{array}{c}\text { Agency } \\
\text { workers } \\
(5)\end{array}$ & Collaborators \\
\hline \multicolumn{7}{|c|}{ Panel A: Excluding firms exposed to regional-sectorial experimentations of the "new" apprenticeship (N=36989) } \\
\hline \multirow[t]{2}{*}{ Reform of Apprenticeship } & -0.0011 & 0.0028 & -0.0066 & 0.0248 & -0.0159 & -0.0173 \\
\hline & $(0.0031)$ & $(0.0055)$ & $(0.016)$ & $(0.0162)$ & $(0.0166)$ & $(0.0178)$ \\
\hline \multirow[t]{2}{*}{ Reform of Fixed term } & $-0.0057^{* *}$ & $0.0119^{* *}$ & $0.0310^{* *}$ & -0.0130 & -0.00244 & 0.0213 \\
\hline & $(0.0023)$ & $(0.0050)$ & $(0.0147)$ & $(0.0151)$ & $(0.0158)$ & $(0.0161)$ \\
\hline \multirow[t]{2}{*}{ Constant } & $0.114^{* * *}$ & $0.113^{* * *}$ & $0.504^{* * *}$ & $0.257^{* * *}$ & $0.225^{* * *}$ & $0.500 * * *$ \\
\hline & $(0.0146)$ & $(0.0248)$ & $(0.0804)$ & $(0.0674)$ & $(0.0549)$ & $(0.0830)$ \\
\hline R-squared & 0.019 & 0.017 & 0.005 & 0.020 & 0.055 & 0.014 \\
\hline \multicolumn{7}{|c|}{ Panel B: Excluding firms of the Banking and Metal manufacturing sector $(\mathrm{N}=31157)$} \\
\hline \multirow[t]{2}{*}{ Reform of Apprenticeship } & -0.0013 & 0.0024 & -0.0256 & 0.0136 & $-0.0318^{*}$ & -0.0306 \\
\hline & $(0.0033)$ & $(0.0059)$ & $(0.0172)$ & $(0.0169)$ & $(0.0173)$ & $(0.0189)$ \\
\hline \multirow[t]{2}{*}{ Reform of Fixed term } & $-0.0076^{* *}$ & 0.0088 & $0.0550 * * *$ & 0.0169 & 0.0278 & 0.0264 \\
\hline & $(0.0029)$ & $(0.0060)$ & $(0.0178)$ & $(0.0183)$ & $(0.0191)$ & $(0.0197)$ \\
\hline \multirow[t]{2}{*}{ Constant } & $0.116^{* * *}$ & $0.119^{* * *}$ & $0.499^{* * *}$ & $0.294^{* * *}$ & $0.212^{* * *}$ & $0.501^{* * *}$ \\
\hline & $(0.0148)$ & $(0.0252)$ & $(0.0812)$ & $(0.0686)$ & $(0.0556)$ & $(0.0840)$ \\
\hline R-squared & 0.018 & 0.017 & 0.005 & 0.025 & 0.054 & 0.016 \\
\hline \multicolumn{7}{|c|}{ Panel C: Model with interaction term $(\mathrm{N}=39857)$} \\
\hline \multirow[t]{2}{*}{ Reform of Apprenticeship } & -0.0036 & 0.0011 & -0.0058 & $0.0304^{*}$ & -0.0085 & -0.0281 \\
\hline & $(0.0029)$ & $(0.0052)$ & $(0.0157)$ & $(0.0155)$ & $(0.0160)$ & $(0.0171)$ \\
\hline \multirow[t]{2}{*}{ Reform of Fixed term } & $-0.0121^{* * *}$ & 0.0080 & 0.0156 & -0.0171 & -0.0003 & 0.0007 \\
\hline & $(0.0032)$ & $(0.0067)$ & $(0.0212)$ & $(0.0204)$ & $(0.0212)$ & $(0.0231)$ \\
\hline \multirow[t]{2}{*}{ Interaction of reforms } & $0.0095^{* *}$ & 0.0054 & 0.0219 & 0.0053 & -0.0054 & 0.0305 \\
\hline & $(0.0037)$ & $(0.0069)$ & $(0.0223)$ & $(0.0214)$ & $(0.0216)$ & $(0.0242)$ \\
\hline \multirow[t]{2}{*}{ Constant } & $0.115^{* * *}$ & $0.114^{* * *}$ & $0.507^{* * *}$ & $0.259^{* * *}$ & $0.225^{* * *}$ & $0.501^{* * *}$ \\
\hline & $(0.0146)$ & $(0.0248)$ & $(0.0805)$ & $(0.0673)$ & $(0.0550)$ & $(0.0830)$ \\
\hline R-squared & 0.018 & 0.018 & 0.005 & 0.022 & 0.053 & 0.014 \\
\hline
\end{tabular}

Note: The dependent variable is the measure of job turnover defined in the text. All regressions include controls for time, region and sector dummies and region- and sector-specific trends. Robust standard errors in parentheses are clustered at the firm level $* * * \mathrm{p}<0.01, * * \mathrm{p}<0.05$, $^{*} \mathrm{p}<0.1$. 
Table 7: The Effect of Reforms on Employment Levels

\begin{tabular}{|c|c|c|c|c|c|c|}
\hline & $\begin{array}{c}\text { Total } \\
\text { employment } \\
\text { (1) }\end{array}$ & $\begin{array}{c}\text { Permanent } \\
\text { contracts } \\
(2)\end{array}$ & $\begin{array}{c}\text { Fixed term } \\
\text { contracts } \\
(3)\end{array}$ & Apprenticeships & $\begin{array}{c}\text { Agency } \\
\text { workers } \\
(5)\end{array}$ & Collaborators \\
\hline \multicolumn{7}{|c|}{ Panel A: Fixed Effects } \\
\hline Reform of Apprenticeship & $\begin{array}{c}0.0013 \\
(0.0029)\end{array}$ & $\begin{array}{c}0.0065 \\
(0.0050)\end{array}$ & $\begin{array}{r}-0.0013 \\
(0.0170)\end{array}$ & $\begin{array}{c}0.0521^{* *} \\
(0.0214)\end{array}$ & $\begin{array}{c}0.0356 \\
(0.0248)\end{array}$ & $\begin{array}{c}-0.0652^{* * *} \\
(0.0200)\end{array}$ \\
\hline Reform of Fixed term & $\begin{array}{c}-0.0093^{* *} \\
(0.0040)\end{array}$ & $\begin{array}{l}-0.0025 \\
(0.0061)\end{array}$ & $\begin{array}{c}0.0040 \\
(0.0233)\end{array}$ & $\begin{array}{l}-0.0119 \\
(0.0314)\end{array}$ & $\begin{array}{c}-0.0931^{* * *} \\
(0.0323)\end{array}$ & $\begin{array}{c}0.0858^{* * *} \\
(0.0276)\end{array}$ \\
\hline Constant & $\begin{array}{c}4.246^{* * * *} \\
(0.171)\end{array}$ & $\begin{array}{c}4.122^{* * *} \\
(0.179)\end{array}$ & $\begin{array}{c}6.033^{* * *} \\
(1.321)\end{array}$ & $\begin{array}{c}3.320 \\
(5.293)\end{array}$ & $\begin{array}{c}6.307^{* *} \\
(2.565)\end{array}$ & $\begin{array}{c}5.862^{* * *} \\
(2.035)\end{array}$ \\
\hline Observations & 53144 & 52932 & 31490 & 14623 & 17834 & 19434 \\
\hline R-squared & 0.013 & 0.006 & 0.016 & 0.028 & 0.035 & 0.016 \\
\hline Number of firms & 13287 & 13286 & 10844 & 6480 & 7175 & 8704 \\
\hline \multicolumn{7}{|c|}{ Panel B: OLS } \\
\hline Reform of Apprenticeship & $\begin{array}{c}0.0073 \\
(0.0253)\end{array}$ & $\begin{array}{c}0.0082 \\
(0.0253)\end{array}$ & $\begin{array}{c}0.0144 \\
(0.0286)\end{array}$ & $\begin{array}{c}0.0540 * \\
(0.0314)\end{array}$ & $\begin{array}{c}-0.113^{* * *} \\
(0.0361)\end{array}$ & $\begin{array}{c}-0.0740^{* * *} \\
(0.0252)\end{array}$ \\
\hline Reform of Fixed term & $\begin{array}{c}0.157^{* * *} \\
(0.0331)\end{array}$ & $\begin{array}{c}0.165^{* * *} \\
(0.0329)\end{array}$ & $\begin{array}{c}0.127^{* * *} \\
(0.0328)\end{array}$ & $\begin{array}{c}0.0285 \\
(0.0322)\end{array}$ & $\begin{array}{c}-0.107^{* * *} \\
(0.0359)\end{array}$ & $\begin{array}{c}0.0970^{* * *} \\
(0.0294)\end{array}$ \\
\hline Constant & $\begin{array}{c}3.087^{* * *} \\
(0.145)\end{array}$ & $\begin{array}{c}3.006^{* * *} \\
(0.145)\end{array}$ & $\begin{array}{c}1.146^{* * *} \\
(0.198)\end{array}$ & $\begin{array}{c}0.448^{* * *} \\
(0.137)\end{array}$ & $\begin{array}{c}1.578^{* * *} \\
(0.346)\end{array}$ & $\begin{array}{c}0.860^{* * *} \\
(0.129)\end{array}$ \\
\hline Observations & 53144 & 52932 & 31490 & 14623 & 17834 & 19434 \\
\hline R-squared & 0.061 & 0.063 & 0.050 & 0.079 & 0.025 & 0.104 \\
\hline
\end{tabular}

Notes: The dependent variable is the log of the number of employees by different contract. All regressions include controls for time, region and sector dummies and region- and sector-specific trends. Robust standard errors in parentheses are clustered at the firm level ${ }^{* * *} \mathrm{p}<0.01,{ }^{* *} \mathrm{p}<0.05,{ }^{*} \mathrm{p}<0.1$. 
Table 8: The Effect of Reforms on Capital, Investment and the Skill Ratio

\begin{tabular}{lccccc}
\hline \hline & Capital & $\begin{array}{c}\text { Capital } \\
\text { per worker }\end{array}$ & Investments & $\begin{array}{c}\text { Investments } \\
\text { per worker }\end{array}$ & Skill ratio \\
& $(1)$ & $(2)$ & $(3)$ & $(4)$ & $(5)$ \\
Reform of Apprenticeship & -0.0070 & -0.0080 & 0.0125 & 0.0148 & -0.0193 \\
& $(0.0056)$ & $(0.0060)$ & $(0.0757)$ & $(0.0761)$ & $(0.0594)$ \\
Reform of Fixed term & $-0.0265^{* * *}$ & $-0.0160^{*}$ & -0.142 & -0.171 & 0.0140 \\
& $(0.0081)$ & $(0.0084)$ & $(0.244)$ & $(0.242)$ & $(0.0720)$ \\
Constant & $13.90^{* * *}$ & $9.642^{* * *}$ & -93.68 & -102.1 & -1.690 \\
& $(0.112)$ & $(0.168)$ & $(92.98)$ & $(93.52)$ & $(2.062)$ \\
& & & & & \\
Observations & 52147 & 52147 & 15440 & 15440 & 53144 \\
R-squared & 0.007 & 0.006 & 0.015 & 0.014 & 0.003 \\
Number of firms & 13267 & 13267 & 9460 & 9460 & 13287
\end{tabular}

Note: All dependent variables are in logs. Investment has 39857 observations but many zeros. All regressions include controls for time, region and sector dummies and region- and sector-specific trends plus firm fixed effects. Robust standard errors in parentheses are clustered at the firm level ${ }^{* * *} \mathrm{p}<0.01,{ }^{* *} \mathrm{p}<0.05,{ }^{*} \mathrm{p}<0.1$. 


\section{Table 9: The Effect of Reforms on Productivity}

Value added per worker Sales per worker TFP

(1)

(2)

(3)

Panel A: Contemporaneous reforms

$\begin{array}{lccc}\text { Reform of Apprenticeship } & 0.0147^{* * *} & 0.0092^{* *} & 0.0162^{* * *} \\ \text { Reform of Fixed term } & (0.0047) & (0.0042) & (0.0046) \\ & -0.0279^{* * *} & -0.0349^{* * *} & -0.0238^{* * *} \\ \text { Constant } & (0.0065) & (0.0058) & (0.0064) \\ & 9.791^{* * *} & 11.61^{* * *} & -0.487 \\ & (0.456) & (0.260) & (0.452) \\ \text { Observations } & & & \\ \text { R-squared } & 52840 & 53144 & 52675 \\ \text { Number of firms } & 0.008 & 0.023 & 0.010 \\ & 13275 & 13287 & 13260\end{array}$

Panel B: Lagged reforms

\begin{tabular}{lccc} 
Reform of Apprenticeship & $0.0131^{* *}$ & 0.0039 & $0.0146^{* * *}$ \\
\multirow{2}{*}{ Reform of Fixed term } & $(0.0055)$ & $(0.0049)$ & $(0.0053)$ \\
& $-0.0274^{* * *}$ & $-0.0363^{* * *}$ & $-0.0248^{* * *}$ \\
Constant & $(0.0065)$ & $(0.0061)$ & $(0.0064)$ \\
& $9.766^{* * *}$ & $11.60^{* * *}$ & -0.517 \\
& $(0.456)$ & $(0.260)$ & $(0.452)$
\end{tabular}

\begin{tabular}{lccc} 
Observations & 52840 & 53144 & 52675 \\
R-squared & 0.008 & 0.023 & 0.010 \\
Number of firms & 13275 & 13287 & 13260 \\
\hline
\end{tabular}

Notes: The dependent variables are in logs, TFP is a residual of a log regression (see text for details). All regressions include controls for time, region and sector dummies and region- and sector-specific trends plus firm fixed effects. Robust standard errors in parentheses are clustered at the firm level ${ }^{* * *} \mathrm{p}<0.01,{ }^{* *} \mathrm{p}<0.05$, $^{*}$ $\mathrm{p}<0.1$. 
Table 10: Robustness Checks on Productivity

Value added per worker Sales per worker

TFP

$(1)$

$(2)$

(3)

Panel A: Excluding firms exposed to regional-sectorial experimentations of the "new" apprenticeship

$\begin{array}{cccc}\text { Reform of Apprenticeship } & 0.0149^{* * *} & 0.0102^{* *} & 0.0165^{* * *} \\ \text { Reform of Fixed term } & (0.0050) & (0.0046) & (0.0049) \\ \text { Constant } & -0.0310^{* * *} & -0.0371^{* * *} & -0.0267^{* * *} \\ & (0.0068) & (0.0060) & (0.0066) \\ & 9.701^{* * *} & 11.56^{* * *} & -0.547 \\ \text { Observations } & (0.493) & (0.279) & (0.488) \\ \text { R-squared } & 49036 & & 48880 \\ \text { Number of firms } & 0.009 & 49320 & 0.011 \\ & 12320 & 0.025 & 12306\end{array}$

Panel B: Excluding firms of the Banking and Metal Manufacturing sector

$\begin{array}{cccc}\text { Reform of Apprenticeship } & 0.0026 & -0.0031 & 0.0044 \\ \text { Reform of Fixed term } & (0.0054) & (0.0049) & (0.0053) \\ & -0.0139^{*} & -0.0213^{* * *} & -0.0104 \\ \text { Constant } & (0.0073) & (0.0064) & (0.0071) \\ & 9.685^{* * *} & 11.28^{* * *} & -0.476 \\ & (0.550) & (0.527) & (0.550) \\ \text { Observations } & & & 41164 \\ \text { R-squared } & 41315 & 41572 & 0.007 \\ \text { Number of firms } & 0.007 & 0.013 & 10597\end{array}$

Panel C: Model with interaction term

$\begin{array}{cccc}\text { Reform of Apprenticeship } & 0.0221^{* * *} & 0.0183^{* * *} & 0.0229^{* * *} \\ \text { Reform of Fixed term } & (0.0053) & (0.0049) & (0.0052) \\ & -0.0132 & -0.0169^{* *} & -0.0105 \\ \text { Interaction of reforms } & (0.0081) & (0.0074) & (0.0078) \\ \text { Constant } & -0.0255^{* * *} & -0.0311^{* * *} & -0.0230^{* * *} \\ & (0.0080) & (0.0073) & (0.0077) \\ & 9.831^{* * *} & 11.61^{* * *} & -0.452 \\ \text { Observations } & (0.302) & (0.0777) & (0.291) \\ \text { R-squared } & & & 52675 \\ \text { Number of firms } & 52840 & 53144 & 0.010 \\ \text { Th } & 0.008 & 0.023 & 13260\end{array}$

Notes: The dependent variables are in logs, TFP is 49 esidual of a log regression (see text for details). All regressions include controls for time, region and sector dummies and region- and sector-specific trends plus firm fixed effects. Robust standard errors in parentheses are clustered at the firm level ${ }^{* * *} \mathrm{p}<0.01,{ }^{* *} \mathrm{p}<0.05, *$ $\mathrm{p}<0.1$. 
Table 11: Elasticity of Substitution across Contract Types

\begin{tabular}{ccccccc}
\hline \hline Year & $2004-2007$ & 2004 & 2005 & 2006 & 2007 \\
$\eta_{\rho}$ (across temporary contracts) & & & & & & \\
& $1.392^{* * *}$ & $1.215^{* * *}$ & $1.802^{*}$ & $1.478^{* * *}$ & -0.780 \\
$\eta_{\sigma}$ (between temporary and permanent contracts) & $1.062^{* * *}$ & $1.070^{* * *}$ & $1.058^{* * *}$ & $1.060^{* * *}$ & $1.056^{* * *}$ \\
& $(0.254)$ & $(0.085)$ & $(0.040)$ & $(0.220)$ & $(0.092)$ \\
Observations & & & & & & \\
& 53145 & 13287 & 13286 & 13286 & 13286
\end{tabular}

